\title{
The effect of soil on Ammi visnaga (L) Lam. plant grown in several localities of Egypt and Sudan
}

\author{
Mokhtar M. Bishr ${ }^{1}$, Samar Yehia Desoukey ${ }^{2 *}$, and Mohamed Magdy ${ }^{1}$ \\ ${ }^{1}$ Research and Development Department, Arab Company for Pharmaceuticals and Medicinal Plants (Mepaco- \\ Medi Food); Sharkyah, Egypt. \\ ${ }^{2 *}$ Department of Pharmacognosy, Faculty of Pharmacy, Minia University, Minia, Egypt, 61519
}

\begin{abstract}
This study shows the effect of soil structure, soil texture and different types of nutrients on the growth of Ammi visnaga ( $L$.) Lam, as well as the yield of the fruit crop and its content of the main active principals ( $\mathrm{y}$ pyrones).

The study was carried out in several localities in Two Arabian countries in North Africa; Egypt and Sudan.

Egypt: at three localities:-1st at Mepaco Farm in Enshas El-Raml, Sharkya Governorate, the2nd at Al-Alfy Farm in Dakahlia Governorate, while the 3rd in Assuit Governorate in Upper Egypt.

Sudan: the first locality is in Abo Halema farm, $20 \mathrm{~km}$ North Khartoum city, the second locality is in WadRaml, about $60 \mathrm{Km}$ North Khartoum.

Source of seeds, the time of seeding, schedule of irrigation, thinning and collection were all fixed. So; the only differences were: the Farmers care for soil and plants as well as soil characteristics.

Soil samples were subjected to elemental analysis to analyze their content of essential (Macro and micro) nutrients, non-essential nutrients as well as non-mineral nutrients. Soil PH, bulk and taped densities were also determined. The number of plants per Fadden, number of umbels per plant, number of rays per umbel and number of fruits per ray were determined. The yield of fruits per Fadden, fruit characteristics and the percentage of total and separate $\gamma$-pyrones were also determined and recorded.
\end{abstract}

Key words: Ammi visnaga, active constituents, crop yield, different localities, effect of soil.

\section{Introduction}

Ammi visnaga plant has many common names (1\& 11); so it is known in Arabic countries as: Khella, Khellah, Khelal, Khella baladi, Gazar sheitani, kammon habashi, Bizr Alkhilla, Kulla, and Sowak Alnabi.

English: Pick tooth, Tooth pick, and Bishop`s weed.

French: Herbe aux cure-dents.

German: Zahnstocherkraut.

Berber: Tabellaout.

Synonyms [1-11] of this plant are: Daucus visnaga L., Selinum visnaga E.H.L. Krause, Sium visnaga Stokes, Visnaga daucoides Gaertn.

Ammi visnaga(L.) Lam. (Apiaceae)[1-10] is a herbaceous annual or biennial plant growing to a height up to 1.3 meter and a diameter of the green aerial parts measuring up to 1.2 meters [1\& 5]. The plant is indigenous to the Mediterranean region, Nile delta and the near east (Iran) [1, 6, 11, 16-20]. The plant is also cultivated in Chile, Argentina, Mexico, US, and Russian ration [1, 6 \& 11].

The stem is erect, robust, highly branched, cylindrical, densely leafy and glabrous. Alternate branching with internodes ranging from 5 to $8 \mathrm{~cm}$ in length where light brown scaly leaves are present at the nodes. It measures up to $130 \mathrm{~cm}$ in length and up to $1.5 \mathrm{~cm}$ in diameter [1\&5].

Leaves are alternate, the basal leaves are pinnately sectioned, ovate in shape, the ultimate segments are slender, linear measuring $20-30 \mathrm{~mm}$ long and $0.5-1 \mathrm{~mm}$ wide, the margin is entire while the apex is acute setaceous. Leaves are sessile in the upper shoots and have short petioles downwards. They are green at the upper region and grayish white in the lower part [1\&5].

Flowers are compound umbels, an umbel is 6-10 cm across; peduncles are elongated, $(6-20 \mathrm{~cm}$ each); with many bracts, which are 1-2-pinnate, equal to or longer than rays; rays ( 50-100-150) per umbel, each is slender, $2-5 \mathrm{~cm}$ long, unequally spreading when young, later in fruiting stage, it becomes thick, rigid, erect and constricted on a discoid torus (thickened base of rays); They are surrounded with an involucre of long filiform tripartite bracts. Bracteoles are numerous, subulate, 3-10 mm, entire, equaling flowers. Florets have a white corolla and calyx with minute inconspicuous sepals, $0.2 \mathrm{~mm}$ [1\& 5].

Fruits are ovoid oblong cremocarps, brownish-green with a violet tinge, they are laterally compressed with thick raised ridges and they are glabrous [1\&11]. (The fruits are the main part used and will be studied in details, here after).The foliage part has a very characteristic smell and the flowers have their own special perfume. 
The root is a cylindrical tap root, light brown in color. The root is straight or slightly tortuous, growing vertically. The surface of the root shows remnants of secondary fibrous rootlets or its scares. The main tap root measures up to $50 \mathrm{~cm}$ in length and $1.5 \mathrm{~cm}$ in the widest upper part [1, 5, 20\& 24].

The Umbels become dry constricted on a discoid torus at the fruiting stage. It measures from 6 to 10 $\mathrm{cm}$ in length and 2 to $4 \mathrm{~cm}$ in width (at the widest part). It becomes light brown in color with characteristic odor and taste [1\& 5]. The ligneous rays of the dry umbels are used as toothpicks [1].

N.B. The sap of the plant has photosensitizing power, so it is advisable to handle the flowers or the whole plant with gloves or wash hands directly with water. The part used as medicament is the dry ripe fruits which contain:

Furanochormones: (y-pyrones); 2- 4\% comprising: Khellin (0.3-1.2\%), visnagin(0.1-0.5\%), others are; khellol and its glucoside, khellenin, khellinol, aminol and its glucoside, visaminol, khellinone and visnaginone

Pyranocoumarins: (Visnagans): 0.2-0.5\% comprising: visnadin, samidin and dihydrosamidin

Furanocoumarines: traces of xanthotoxin and amoidin . Flavonoids: $0.02-0.05 \%$ comprising quercetin, and isorhamnetin and their 3-sulphates as well as kaempferol ,Volatile oil: $0.2-0.4 \%$ composed of camphor, carvone, terpineol, terpinen-4-ol, linalool, cis and trans linalool oxides with Fixed oil: about 12-18\% and

Protein: $12-16 \%$.

The dried ripe fruits, due to their contents of the $\mathrm{y}$-pyrones, are smooth muscle relaxant and have antispasmodic effect ( $1 \& 11)$, where the fruits are used to help the passage of renal calculi through the lowering of the tonicity of the ureter $[1,6,8,10,11,14,15,20 \& 21]$. Also they are used to relax the smooth muscles of the bronchi, coronary vessels and gastrointestinal tract, hence their use in treatment of bronchial asthma [1\&14] angina pectoris, cardiac insufficiency [1, 26-29], biliary and intestinal colic [1\& 11].

The dry or liquid standardized extracts of Ammi visnaga as well as pure active principals (khellin) are used in pharmaceutical industry for the manufacture of many pharmaceutical products [1, 12, and 13].

The Pharmaceutical products available are:-

\section{1-In the Egyptian market:}

Kellagon capsules \& effervescent sachets (Mepaco Co.)

Khellalgin ampoule (Misr Co).

Gluclynamine (Memphis Co.).

2-Global products:

Ammi visnaga Drops, Globules\& Granules, Bioron Laboratories (France)

Vibeline, Promesa (Spain).

Aesrutal S, Steigerwald (Germany).

Carduben, Madaus (Germany).

Khellangan N, Ardeypharm (Germany).

Steno-loges N, Loges (Germany).

\subsection{Equipments:-}

\section{Material and Methods:}

The Sonicator (Nexx Sonic, NS-A-12-7H, Made in Germany) TLC plates: - Readymade TLC Silica $\mathrm{GF}_{254}$ plate, (Aluminum sheets 20x20cm, Merck, Germany), application was performed by, Camag applicator (Model: Camag Linomet 5, Switzerland),

Scanning and analysis: Shimadzu TLC-scanner (Model: CS-9301 Pc, MRD-20, Japan), using the zigzag mode at wave length of $\kappa 250 \mathrm{~nm}$. The results- peaks and areas -were recorded automatically through the software and computer connected to the scanner. Germany).

The bulk density was determined using a Tapped Volumeter Machine (Erweka Type: SVM202,

Elemental analysis was done by using electron microscope: Model: Joel, GSM-6360LA.Analytical Screening Electron Microscope. The analysis was carried out following EDS method (Energy Dispersive Spectroscopy), on compressed soil powder.

PH meter, (Model Jenway 3510, MRD-26, UK); which was pre-calibrated using Fluka standard buffer solution of $\mathrm{PH}$ 4, 7 and 10. 
The effect of soil on Ammi visnaga (L) Lam. plant grown in several localities of Egypt and Sudan

\subsection{Plant Material:}

Seeds for the production of all the crops were all obtained from the same source (Mepaco Co.). Random samples of the mature air dried Ammi visnaga (L.) Lam fruits, were collected from each supply of the different localities, and were identified \& examined morphologically, microscopically and chemically. After that a retained sample from each supply was kept in the herbarium of the Research and Development Department in Mepaco Company.

\subsubsection{Determination of fruit weight:}

A Hundred fruits of each locality were taken from each sample and weighed. Three determinations were carried out. The mean for each sample was calculated.

\subsection{Preparation of the liquid extracts (1:1):}

After many trials it was found that the use of $30 \%$ ethanol for extraction gives the highest content of $y$ pyrones. So; $\mathbf{1 0} \mathbf{~ g}$ of Ammi visnaga fruits of each locality were shaken with $\mathbf{2 0 0} \mathbf{~ m l}$ of $30 \%$ ethanol for six hours, set aside for 18 hours and then filtered. The marc washed with $50 \mathrm{ml}$ fresh $30 \%$ ethanol. Washing added to filtrate and concentrated under vacuum at $50^{\circ} \mathrm{C}$ to $10 \mathrm{~g}$ (as final weight).

\subsubsection{Determination of the total solids in each of the extract:}

In a clean weighed porcelain dish, $5 \mathrm{ml}$ of each of the extracts obtained from each locality were accurately measured, evaporated to dryness over a water bath, cooled, desiccated and reweighed. The percentages of total solids were calculated. The mean of three determinations were recorded.

\subsubsection{Determinations of total and separate y-pyrones in the extract:}

\subsubsection{Sample preparation:}

$50 \mathrm{mg}$ of the dried residue for each locality obtained in the above step were weighed, dissolved in HPLC grade methanol adjusted to a volume of $50 \mathrm{ml}$ in a volumetric flask, sonicated for ten minutes and filtered if necessary.

\subsubsection{Standard preparation:}

Dissolve $20 \mathrm{mg}$ pure khellin (Tardy, France) in $100 \mathrm{ml}$ HPLC grade methanol using a suitable volumetric flask.

\subsection{Analysis of the liquid extracts:}

2.4.1 Sample and standard application:

$5 \mu \mathrm{l}$ of each of the tested samples solutions alongside with six bands of the standard solution were applied to a readymade TLC Silica $\mathrm{GF}_{254}$ plate using the Camag applicator.

\subsubsection{Development of the TLC plates:}

The plates were developed using solvent system; Benzene-Ethyl acetate (65:35).

\subsubsection{Scanning and analysis of the TLC plates:}

The whole lanes on the TLC plate of both sample and standard were scanned using Shimadzu TLCscanner, the zigzag mode at wave length of $\kappa 250 \mathrm{~nm}$. Peaks and areas were recorded automatically through the software and computer connected to the scanner.

\subsection{Soil samples:}

The soil samples of the different localities of the plant samples (fruits) were collected from a depth of $20-25 \mathrm{~cm}$. The litter on the surface of the soil was removed, kept in PVC jars, labeled and brought to laboratory.

\subsubsection{Soil analysis:}

2.5.1.1 Elemental analysis; was done by using Electron microscope: The analysis was carried out following EDS method (Energy Dispersive Spectroscopy), on compressed soil powder.

\subsubsection{Bulk and Taped Density:}

The bulk density was determined for each sample using a Tapped volumetric Machine. A fifty gram sample from each of the different localities of the powdered soil, was passed through a sieve of $500 \mu \mathrm{m}$ pores, and introduced into the instrument graduated cylinder $(250 \mathrm{ml})$. The powder volume of the specified weight was determined visually. The mean of three determinations was performed. The bulk density was calculated by dividing the weight of the powder by its visually determined volume. 
The tapped density was determined, by mechanically tapping the measuring cylinder containing the soil powder - up to 500 strokes, until no change in the volume was observed- and the volume was recorded. The tapped density was calculated by dividing the weight of the powder by its visually determined volume after tapping.

\subsubsection{Determination of Soil PH:}

Five grams of finely powdered soil was extracted by $100 \mathrm{ml}$ distilled water, by shaking at room temperature for six hours, set aside overnight then filtered. The $\mathrm{PH}$ of the filtrate was measured using $\mathrm{pH}$ meter. Three determinations were carried out for each soil sample and the mean was recorded.

\subsection{Plant growth parameters in each locality:}

\section{Results:}

Several parameters for the plants grown in each locality were determined. The determinations were carried out when the plants were fully grown at the collection time. These parameters were:

- $\quad$ Number of plants per Fadden.

- $\quad$ Height and diameter (at the widest part) of foliage part of the plant.

- $\quad$ Number of umbels per plant, number of rays per umbel and number of fruits per ray.

- Weight of 100 fruits, and an average of three determinations.

- $\quad$ The yield of dried ripe fruits per Fadden.

It was very clear that the number of plants per Fadden were inversely proportional to the plants` dimensions and the yield of crop per Fadden in kg. where Wad-Raml farm showed the highest number of plants with the lowest plant dimensions and crop yield, while the complete opposite was shown with Al Alfy farm as seen in Table 1.

\subsection{The percentage of total solids and $\mathrm{y}$-pyrones}

The Percentage of total solids and percentage of $\gamma$-pyrones in these solids, in the liquid extracts in each locality was determined and was found to be the highest in Al Alfy farm and the lowest in Abo-Halema farm.

\subsection{The total \& separate pyrones relative to each locality:}

The quantitative results obtained from scanning the TLC plates were the mean of six determinations for each sample and the results showed that Al Alfy farm has the highest total pyrones and the lowest was AboHalema Farm, but the proportion of the two major pyrones in all samples were nearly the same.

\subsection{The soil analysis for nutrients:}

The highest oxygen was present in Al Alfy farm, while the highest manganese was present in Abo-Halema farm.

\subsection{The pH, bulk and tapped density for the soils samples of each of the localities}

It was clear that the Al Alfy farm was of a slightly acidic $\mathrm{pH}$ (6.8), and the highest difference between Tapped and Bulk density, showing good aeration.

\section{Tables}

Table 1: Shows the parameters of plant growth in each locality:

\begin{tabular}{|c|c|c|c|c|c|c|c|}
\hline $\begin{array}{l}\text { Locality } \\
\text { and Country }\end{array}$ & $\begin{array}{l}\text { Number } \\
\text { of Plants/ } \\
\text { Fadden }\end{array}$ & $\begin{array}{l}\text { Height } \\
\text { of the Plant }\end{array}$ & $\begin{array}{l}\text { Diam. } \\
\text { Areal } \\
\text { Part, Cm. }\end{array}$ & $\begin{array}{l}\text { No. of Umbels } \\
\text { / Plant }\end{array}$ & $\begin{array}{l}\text { No. of Rays/ } \\
\text { Umbel } \\
\& \text { No. of } \\
\text { fruits/ray }\end{array}$ & $\begin{array}{l}\text { Wt. of fruit\& } \\
\text { dimensions }\end{array}$ & $\begin{array}{l}\text { Yield/ } \\
\text { Fadden } \\
\text { Kg. }\end{array}$ \\
\hline $\begin{array}{l}\text { Mepaco, } \\
\text { Farm, } \\
\text { Sharkyah; } \\
\text { Egypt }\end{array}$ & 15500 & $\begin{array}{l}100-110 \\
\mathrm{~cm}\end{array}$ & $\begin{array}{l}\text { Up to } \\
110 \mathrm{~cm}\end{array}$ & 26 & $\begin{array}{l}70 \text { Rays } \\
25 \text { fruits }\end{array}$ & $\begin{array}{l}0.712 \mathrm{mg} \\
\mathrm{L}=2.1 \mathrm{~mm} \\
\mathrm{~W}=0.9 \mathrm{~mm} \\
\mathrm{Th}=0.8 \mathrm{~mm}\end{array}$ & 500 \\
\hline $\begin{array}{l}\text { Al-Alfy } \\
\text { Farm, Dekahlia; } \\
\text { Egypt }\end{array}$ & 15000 & $\begin{array}{l}110-120 \\
\mathrm{~cm}\end{array}$ & $\begin{array}{l}\text { Up to } \\
120 \\
\mathrm{~cm}\end{array}$ & 30 & $\begin{array}{l}80 \text { Rays } \\
27 \text { fruits }\end{array}$ & $\begin{array}{l}0.766 \mathrm{mg} \\
\mathrm{L}=2.3 \mathrm{~mm} \\
\mathrm{~W}=1.0 \mathrm{~mm} \\
\mathrm{Th}=0.9 \mathrm{~mm}\end{array}$ & 740 \\
\hline $\begin{array}{l}\text { Assuit Farm; } \\
\text { Egypt }\end{array}$ & 17200 & $\begin{array}{l}90-100 \\
\mathrm{~cm}\end{array}$ & $\begin{array}{l}\text { Up to } \\
100 \mathrm{~cm}\end{array}$ & 23 & $\begin{array}{l}60 \text { Rays } \\
22 \text { fruits }\end{array}$ & $\begin{array}{l}0.799 \mathrm{mg} \\
\mathrm{L}=2.5 \mathrm{~mm} \\
\mathrm{~W}=1.1 \mathrm{~mm} \\
\mathrm{Th}=1.0 \mathrm{~mm}\end{array}$ & 415 \\
\hline $\begin{array}{l}\text { Wad-Raml } \\
\text { Farm; } \\
\text { Sudan }\end{array}$ & 19300 & $\begin{array}{l}80-90 \\
\mathrm{~cm} .\end{array}$ & $\begin{array}{l}\text { Up to } \\
70 \mathrm{~cm}\end{array}$ & 15 & $\begin{array}{l}50 \text { Rays } \\
20 \text { fruits }\end{array}$ & $\begin{array}{l}0.830 \mathrm{mg} \\
\mathrm{L}=2.7 \mathrm{~mm} \\
\mathrm{~W}=1.1 \mathrm{~mm} \\
\mathrm{Th}=1.0 \mathrm{~mm}\end{array}$ & 236 \\
\hline $\begin{array}{l}\text { Abo-Halema } \\
\text { Farm; } \\
\text { Sudan }\end{array}$ & 18300 & $75-90 \mathrm{~cm}$ & $\begin{array}{l}\text { Up to } \\
80 \mathrm{~cm}\end{array}$ & 16 & $\begin{array}{l}55 \text { rays } \\
21 \text { Fruits }\end{array}$ & $\begin{array}{l}0.843 \mathrm{mg} \\
\mathrm{L}=2.8 \mathrm{~mm} \\
\mathrm{~W}=1.2 \mathrm{~mm} \\
\mathrm{Th}=1.0 \mathrm{~mm}\end{array}$ & 298 \\
\hline
\end{tabular}


The effect of soil on Ammi visnaga (L) Lam. plant grown in several localities of Egypt and Sudan

Table 2: Shows Percentage of total solids in the liquid extracts:

\begin{tabular}{|l|l|l|l|l|l|}
\hline Result & $\begin{array}{l}\text { Mepaco } \\
\text { Farm }\end{array}$ & $\begin{array}{l}\text { Al-Alfy } \\
\text { Farm }\end{array}$ & $\begin{array}{l}\text { Assuit } \\
\text { Farm }\end{array}$ & $\begin{array}{l}\text { Wad-Raml } \\
\text { Farm }\end{array}$ & $\begin{array}{l}\text { Abo-Halema } \\
\text { Farm }\end{array}$ \\
\hline \% total solids & 18.54 & 19.27 & 17.96 & 17.53 & 17.30 \\
\hline $\begin{array}{l}\text { \% of total y-pyrones } \\
\text { In the total solids }\end{array}$ & 16.45 & 17.68 & 14.60 & 13.53 & 12.24 \\
\hline
\end{tabular}

Table 3: Shows the total \& separate pyrones relative to each locality:

The quantitative results obtained from scanning of the TLC are the mean of six determinations for each sample.

\begin{tabular}{|c|c|c|c|}
\hline \multirow{3}{*}{$\begin{array}{l}\text { Locality } \\
\text { and } \\
\text { Country }\end{array}$} & \multirow[t]{3}{*}{$\begin{array}{l}\text { Total y- } \\
\text { Pyrones }\end{array}$} & & \\
\hline & & \multicolumn{2}{|c|}{$\%$ of the two main $y$-Pyrones in the total } \\
\hline & & Khellin & Visnagin \\
\hline $\begin{array}{l}\text { Mepaco Farm, } \\
\text { Sharkyah, Egypt }\end{array}$ & $3.04 \%$ & $36.83 \%$ & $17.38 \%$ \\
\hline $\begin{array}{l}\text { Al-Alfy } \\
\text { Farm, Egypt }\end{array}$ & $3.40 \%$ & $38.80 \%$ & $18.30 \%$ \\
\hline Assuit Farm, Egypt & $2.62 \%$ & $31.55 \%$ & $13.60 \%$ \\
\hline $\begin{array}{l}\text { Wad-Raml } \\
\text { Farm, Sudan }\end{array}$ & $2.37 \%$ & $30.66 \%$ & $13.94 \%$ \\
\hline $\begin{array}{l}\text { Abo-Halema } \\
\text { Farm, Sudan }\end{array}$ & $2.11 \%$ & $29.83 \%$ & $14.08 \%$ \\
\hline
\end{tabular}

Table 4: Shows the results of the soil analysis for nutrients:

\begin{tabular}{|c|c|c|c|c|c|}
\hline \multirow{3}{*}{$\begin{array}{l}\text { Locality } \\
\text { and } \\
\text { Country }\end{array}$} & \multicolumn{3}{|c|}{ Essential Nutrients } & \multirow{3}{*}{$\begin{array}{l}\text { Non- } \\
\text { Essential } \\
\text { Nutrients } \\
\text { (element } \\
\text { Mass \%) }\end{array}$} & \multirow{3}{*}{$\begin{array}{l}\text { Non- } \\
\text { Mineral } \\
\text { Nutrient } \\
\text { (element } \\
\text { Mass \%) }\end{array}$} \\
\hline & \multicolumn{2}{|c|}{$\begin{array}{l}\text { Macro } \\
\text { (element } \\
\text { Mass \%) }\end{array}$} & \multirow[t]{2}{*}{$\begin{array}{l}\text { Micro } \\
\text { (element } \\
\text { Mass \%) }\end{array}$} & & \\
\hline & $1^{\circ}$ ry & $2^{\circ}$ ry & & & \\
\hline $\begin{array}{l}\text { Mepaco Farm, } \\
\text { Sharkyah, Egypt }\end{array}$ & $\begin{array}{l}K=1.17 \\
P=0.12\end{array}$ & $\begin{array}{l}\mathrm{Ca}=1.60 \\
\mathrm{Mg}=2.43 \\
\mathrm{~S}=0.05\end{array}$ & $\begin{array}{l}\mathrm{Fe}=9.21 \\
\mathrm{Mn}=0.009 \\
\mathrm{Zn}=1.49 \\
\mathrm{Cu}=0.006\end{array}$ & $\begin{array}{l}\mathrm{Na}=0.00 \\
\mathrm{Al}=8.79\end{array}$ & $\begin{array}{l}\mathrm{O}=43.68 \\
\mathrm{C}=13.22\end{array}$ \\
\hline $\begin{array}{l}\text { Al-Alfy } \\
\text { Farm, } \\
\text { Egypt }\end{array}$ & $\begin{array}{l}K=1.10 \\
P=0.15\end{array}$ & $\begin{array}{l}\mathrm{Ca}=1.75 \\
\mathrm{Mg}=2.59 \\
\mathrm{~S}=0.02\end{array}$ & $\begin{array}{l}\mathrm{Fe}=1.38 \\
\mathrm{Mn}=0.005 \\
\mathrm{Zn}=0.99 \\
\mathrm{Cu}=0.040\end{array}$ & $\begin{array}{l}\mathrm{Na}=0.00 \\
\mathrm{Al}=7.12\end{array}$ & $\begin{array}{l}O=50.62 \\
C=20.95\end{array}$ \\
\hline $\begin{array}{l}\text { Assuit } \\
\text { Farm, } \\
\text { Egypt }\end{array}$ & $\begin{array}{l}\mathrm{K}=1.07 \\
\mathrm{P}=0.21\end{array}$ & $\begin{array}{l}\mathrm{Ca}=1.82 \\
\mathrm{Mg}=1.84 \\
\mathrm{~S}=0.01\end{array}$ & $\begin{array}{l}\mathrm{Fe}=5.51 \\
\mathrm{Mn}=0.007 \\
\mathrm{Zn}=0.95 \\
\mathrm{Cu}=0.004\end{array}$ & $\begin{array}{l}\mathrm{Na}=0.00 \\
\mathrm{Al}=7.99\end{array}$ & $\begin{array}{l}\mathrm{O}=44.66 \\
\mathrm{C}=10.01\end{array}$ \\
\hline $\begin{array}{l}\text { Wad-Raml } \\
\text { Farm, } \\
\text { Sudan }\end{array}$ & $\begin{array}{l}\mathrm{K}=0.19 \\
\mathrm{P}=0.31\end{array}$ & $\begin{array}{l}\mathrm{Ca}=1.88 \\
\mathrm{Mg}=1.75 \\
\mathrm{~S}=0.32\end{array}$ & $\begin{array}{l}\mathrm{Fe}=11.92 \\
\mathrm{Mn}=0.74 \\
\mathrm{Zn}=0.35 \\
\mathrm{Cu}=0.003\end{array}$ & $\begin{array}{l}\mathrm{Na}=0.30 \\
\mathrm{Al}=8.60\end{array}$ & $\begin{array}{l}\mathrm{O}=44.62 \\
\mathrm{C}=9.12\end{array}$ \\
\hline $\begin{array}{l}\text { Abo-Halema } \\
\text { Farm, } \\
\text { Sudan }\end{array}$ & $\begin{array}{l}\mathrm{K}=0.33 \\
\mathrm{P}=0.49\end{array}$ & $\begin{array}{l}\mathrm{Ca}=2.93 \\
\mathrm{Mg}=1.63 \\
\mathrm{~S}=0.24\end{array}$ & $\begin{array}{l}\mathrm{Fe}=7.77 \\
\mathrm{Mn}=1.37 \\
\mathrm{Zn}=0.12 \\
\mathrm{Cu}=0.010\end{array}$ & $\begin{array}{l}\mathrm{Na}=0.17 \\
\mathrm{Al}=8.14\end{array}$ & $\begin{array}{l}\mathrm{O}=46.07 \\
\mathrm{C}=12.07\end{array}$ \\
\hline
\end{tabular}

Table 5: Shows the result obtained for PH, bulk and tapped density

\begin{tabular}{|l|l|l|l|l|l|}
\hline $\begin{array}{l}\text { Locality and } \\
\text { Country }\end{array}$ & PH & $\begin{array}{l}\text { Bulk } \\
\text { Density }\end{array}$ & $\begin{array}{l}\text { Tap. } \\
\text { Density }\end{array}$ & $\begin{array}{l}\text { Difference } \\
\text { Tap. density -Bulk } \\
\text { Density }\end{array}$ & $\begin{array}{l}\text { Porosity } \\
\text { Rating } \\
\text { (Descending) }\end{array}$ \\
\hline $\begin{array}{l}\text { Mepaco Farm, } \\
\text { Sharkyah, Egypt }\end{array}$ & 7.1 & 1.127 & 1.249 & 0.122 & $\mathbf{5}$ \\
\hline $\begin{array}{l}\text { Al-Alfy Farm, } \\
\text { Egypt }\end{array}$ & 6.8 & 1.102 & 1.323 & 0.221 & $\mathbf{1}$ \\
\hline Assuit Farm, Egypt & 7.6 & 1.115 & 1.285 & 0.170 & $\mathbf{3}$ \\
\hline $\begin{array}{l}\text { Wad-Raml } \\
\text { Farm,Sudan }\end{array}$ & 8.0 & 1.114 & 1.277 & 0.163 & $\mathbf{4}$ \\
\hline $\begin{array}{l}\text { Abo-Halema } \\
\text { Farm, Sudan }\end{array}$ & 7.8 & 1.064 & 1.237 & 0.173 & $\mathbf{2}$ \\
\hline
\end{tabular}




\section{Conclusion and Discussion}

From the previous data, one may conclude that the foliage part of the plant and its dimensions (height and diameter), were directly affected by the quality of husbandry and custody in the various stages of plant life. So good tillage was reflected on the aeration of the soil, as seen in Table 4. Moreover; the addition of super phosphate with sufficient amount at the preparation stage of the soil, not only supported plant cell division and storage of energy through ATP \& ADP, but also helped root development and the biosynthesis of the chemical constituents in the plant. This is quite clear in Alfy Farm >Mepaco Farm>Assuit Farm>Abo-Halema Farm then Wad-Raml Farm, as seen in Table 1 and 3.

Good thinning helps the plant to grow freely and affects the plant dimension as seen in Table 1, where the numbers of plants per Fadden were in the following manner: Wad-Raml Farm>Abo-Halema Farm> Assuit Farm >Mepaco Farm> Al-Alfy Farm. This was found to be inversely proportional to the plant size Table 1.

Weed removal and control gave the plant a chance to take complete benefit from the naturally occurring nutrients in the soil as well as the added nutrients during the plant life stages. It was found to be directly proportional to plant growth and its chemical content as seen in Tables; 1,2 and 3.

The addition of Urea fertilizer as a source of $\mathrm{N}$, with sufficient amount (50 kg/Fadden), three times starting from the second month with careful irrigation and drainage, gives pronounced results and this was clear according to our notes on the custody in various farms. We found that Al-Alfy farm was the best followed by Mepaco as shown in Table 1.

Only Al-Alfy Farm tended to use an extra foliar fertilizer with the composition: N: K: P :( equal amount of $\mathrm{Cu}+\mathrm{Fe}+\mathrm{Mn}+\mathrm{S}+\mathrm{Zn}+\mathrm{Mg}$ and $\mathrm{Ca}$ ) in the ratio of 20:20:20:(40). This extra care of Al-Alfy to the plant was reflected on the size of the plant (height and diameter), number of umbels/plant, number of rays/umbel and number of fruits/ray. As well as the overall yield of the fruits/Fadden. Not only the yield of the fruits/Fadden increased but also the percentage of the total $y$-pyrones in the fruit.

It is well known that the micro essential element, manganese (Mn), has direct effect on the size (length and width) of seed in the fruit. So, plants grown on $\mathrm{Mn}$ in a concentration of 0.0003 to $0.003 \mathrm{M}$, gave the largest seed size and hence weight [30]. The previously mentioned fact is very clear in our study, where plants grown in Abo-Halema Farm (Mn concentration is $0.00137 \mathrm{M}$ in its soil) gives fruits of average weight $0.843 \mathrm{mg} /$ fruit, length $2.8 \mathrm{~mm}$, width $1.2 \mathrm{~mm}$ and thickness $1.0 \mathrm{~mm}$. followed by plants grown in Wad-Raml Farm (Mn concentration is $0.00074 \mathrm{M}$ in its soil) gives fruits of average weight $0.830 \mathrm{mg} /$ fruit, length $2.7 \mathrm{~mm}$, width 1.1 $\mathrm{mm}$ and thickness $1.0 \mathrm{~mm}$, then comes plants grown in Assuit, Al-Alfy Farm and finally that grown in Mepaco Farm Farm (where Mn concentration is about to be zero in their soils)they give fruits of average weight and dimensions as follow: $0.799 \mathrm{mg}$ ( $2.5 \mathrm{~mm}$ length, $1.1 \mathrm{~mm}$ width and $1.0 \mathrm{~mm}$ thick), $0.766 \mathrm{mg}$ (length $2.3 \mathrm{~mm}$, width $1.0 \mathrm{~mm}$ and thickness $0.9 \mathrm{~mm}$ ) and $0.712 \mathrm{mg}$ (length $2.1 \mathrm{~mm}$, width $0.9 \mathrm{~mm}$ and thickness $0.8 \mathrm{~mm}$ ) respectively. Although, Al-Alfy tends to add excess Mn through the foliar spray fertilizer, it cannot reach the fruit size and weight given by soils naturally rich in that element. On the other hand, Mepaco has an expert team for cultivation, but the overall yield of the fruits is not so good; this may be due to continuous and successive cultivation of Ammi visnaga for several years in the same area. Obviously this lead to depletion of the soil from the essential macro and micro nutrients, results were shown in Table 1. It is recommended for Mepaco Farm in particular and other Farms to make rotation for cultivation of different plants in the same area.

From table 5, it was found that the indicative parameters:- Bulk and Tapped density (porosity) are in accordance with $\%$ of $\mathrm{O}_{2}$ in all analyzed soil samples and are in the order: Al-Alfy Farm> Abo-Halema Farm> Assuit Farm>Wad Raml Farm >Mepaco Farm.

$\mathrm{PH}$ of the soil is regarded an important factor that affects the plant growth, where neutral or slight acidic pH 6.8 is the best for the availability of the essential nutrients in the soil. This was reflected on the given yield of various Farms Table 1 and 5.

Winter (season for cultivation of Ammi visnaga) in Delta and North Egypt is of moderate temperature and raining. In Assuit, it is warmer and less rainy while in Sudan, it is hot and least rainy. This can explain the suitability of climates in Nile Delta and North Egypt for the cultivation of Ammi visnaga.

Although, the fore mentioned factors affect the percentage of the total y-pyrones in the fruits of Ammi visnaga, but it has no effect on the relative ratio of khellin/visnagin which is almost 2.11.

From all the above it is quite obvious that soil structure \& content affects the Ammi visnaga plant dimensions and secondary metabolites. The most suitable soil and probably climate for Ammi visnaga plant was shown to be Al-Alfy Farm.

\section{References}

[1]. Josef A. Brinckmann and Michael P. Lindenmaier; "Herbal Drugs and Phytopharmaceuticals, $2^{\text {nd }}$ English edition, Medpharm Scientific Publisher, 2002, 34.

[2]. Hegnauer R, Chemical Patterns and relationships of Umbellifarae (Academic Press, New York, 1971.)

[3]. Hegnauer R, Chemotaxonomy of Plants (Basil Birkhauser, 1973.)

[4]. Rechinger KH, Family Umbellifarae (Akademische Druck-u, Verlagsanstalt, Graz, Austria.-1972) 
[5]. International Union for Conservation of Nature (IUCN) A guide to Medicinal Plants in North Africa (IUCN, Malaga, Spain, 2005.)25-26

[6]. T.E.Wallis, Text Book of Pharmacognosy ( $5^{\text {th }}$ edition, CBS Publishers and Distributors, Delhi, India, 1985, 244.)

[7]. Central Council for Research in Unani Medicine, Standardization of Drugs of Unani Medicine ( Part I, $1^{\text {st }}$ Edition, Baharat Press, New Delhi, India, 1987, 170

[8]. Montvale NJ ,PDR for Herbal Medicines ( $3^{\text {rd }}$ edition, Medical Economics Co., 2004, 84)

[9]. Trease and Evans, Pharmacognosy (14 ${ }^{\text {th }}$ edition, WB Saunders Co., UK, 1999, 251.)

[10]. German Homeopathic Pharmacopoeia (Vol. 1, General Part, Medpharm Scientific publishers, Stuttgart, Germany, 2003, 4)

[11]. WHO Monographs on Selected Medicinal Plants (Vol. 3, World Health Organization, 2007, 23)

[12]. Sitting M, Pharmaceutical Manufacturing Encyclopedia", Noyes Publications, USA, 1988.

[13]. Kleeman A et al, Pharmaceutical Substances, syntheses, Patents, Applications. Thieme Stuttgart, 1999.

[14]. Satrani B et al,, Chemical Composition, Antimicrobial and antifungal Activities of the Essential oil of Ammi visnaga (L.) Lam from Morocco, Acta Bot. Gal. (15(1), 2004, 65-71)

[15]. Ayda K et al, Variability of Two Essential Oils of Ammi visnaga L. a Traditional Tunisian Medicinal Plant, Journal of Medicinal Plants Research (Vol. 5(20), 2011, 5079)

[16]. African Pharmacopoeia (Vol. 1, Lagos, organization of African Unity, Scientific, Technical and Research commission, 1985)

[17]. Bisser NG, Herbal Drugs and Phytopharmaceuticals (Boca Raton, FL, CRC Press, 1994)

[18]. Zargari A., Medical Plants (Vol. 2, $4^{\text {th }}$ edition, Tehran University, 1989)

[19]. Flora Reipublicae Popularis sinicae (Thomas 55, China, Science Press, 1985)

[20]. Bruneton J, Pharmacognosy, Phytochemistry and Medicinal Plants, Paris, Lavoisier, 1995)

[21]. Abou Mostafa EA et al, a Further Contribution to the f-Pyrone Constituents of Ammi visnaga Fruits, Planta Medica, 56,1990, 134)

[22]. El-Domiaty MM., Improved High Performance Liquid Chromatographic Determination of Khellin and Visnagin in Ammi visnaga Fruits and Pharmaceutical Formulations, J. of Pharmaceutical Sciences, 8, 1992, 375-478.

[23]. Martelli $\mathrm{P}$ et al, Rapid Separation and Quantitative Determination of Khellin and Visnagin in Ammi visnaga dicaL. Fruits by High Performance Liquid Chromatography, Journal of Chromatography, 301, 1984, 297-302.

[24]. Franchi GG et al, High Performance Liquid chromatography analysis of the Furanochromones Khellin and Visnagin in Various Organs of Ammi visnaga L. at Different Development Stages, Journal of Ethnopharmacology, 14,1985, $203-212$.

[25]. Ganzera M, Sturm S, Stupper H, HPLC-MS and MECC analysis of Coumarins, Chromatographia, 46,1997,197-203.

[26]. Rauwald HW, Brehm H, Odenthal KP, The Involvement of Ca channel Blocking Mode of Action in the Pharmacology of Ammi visnaga Fruits, Planta Medica, 60,1994,101-105.

[27]. Duarte J et al, Vasodilator Effects of Visnagin in Isolated Rat Vascular smooth Muscle, European Journal of Pharmacology, 286, $1995,115-122$

[28]. Duarte J et al, Effects of Visnadin on Isolated Rat Vascular Smooth Muscles, Planta Medica, 63,1997,233-236

[29]. Galal EE, Kandil A, Latif MA, Evaluation of Cardiac Inotropism of Ammi visnaga .Principals by the Intra-Ventricular Technique, Journal of Drug Research of Egypt, 7,1975, 745-57.

[30]. Sladana Todorovic et al, Manganese effects on in vitech. Biol.Sci. Belgrade, 61(2), 2009, $279-283$. 